\title{
LEITURA E PRAZER ESTÉTICO: exercícios literários e poéticos em classe de jovens e adultos
}

\author{
Raimundo Nonato de Oliveira Falabelo \\ Universidade Federal do Pará - UFPA, Brasil
}

\begin{abstract}
Resumo
O objetivo deste artigo é apresentar o resultado do que chamo de pequenos exercícios poéticos realizados numa classe de Educação de Jovens e Adultos, trabalho cujo guia foi o desejo de configurar a leitura literária como instância de experiência, desenvolvimento intelectual, fruição afetivo-emocional e prazer estético. Ele fundamenta-se na perspectiva histórico cultural do desenvolvimento humano, para o qual a linguagem é o instrumento de apropriação das significações por excelência - modos de ser, atuar, sentir e apropriar-se da cultura. Metodologicamente, estudaram-se os eventos em suas condições concretas de produção, apreendendo indícios e evidências que eram passíveis de serem percebidas na interação com o objeto artístico. Esses exercícios sugerem que a prática da leitura literária escolar deveria tomar como pressuposto que o gosto decorre das significações e dos sentidos em funcionamento, na corrente viva da linguagem. Recomenda a formação literária, como orientação teórica, metodológica e didática, estimular e valorizar, na interação obra/leitor(a), a elaboração do que o aluno vive e sente, ampliando sua experiência, seu pensamento e a fruição do seu prazer estético.
\end{abstract}

Palavras-chave: Leitura; Poesia; Emoção; Prazer estético.

\begin{abstract}
The objective is to present the result of what I call small poetic exercises performed in a Youth and Adult Education class, guided by the desire to configure literary reading as instances of experience, intellectual development and affective-emotional enjoyment and aesthetic pleasure. It is based on the historical cultural perspective of human development, for which language is the instrument par excellence of appropriating meanings, ways of being acting, feeling and appropriating culture. Methodologically, the events were studied in their concrete conditions of production, apprehending clues, evidences that were seen in the interaction with the artistic object. These exercises suggest that the practice of school literary reading should, therefore, consider as an assumption that taste derives from meanings and senses at work, in the living current of language. For literary training, it is recommended, as a theoretical, methodological and didactic orientation, in the work-reader interaction, to stimulate and value the elaboration of what the student lives and feels, expanding his experience, his thinking and the enjoyment of aesthetic pleasure.
\end{abstract}

Keywords: Reading; Poetry; Emotion; Pleasure aesthetic.

ISSN 1645-1384 (online) www.curriculosemfronteiras.org 


\section{Introdução}

Aquilo que se nomeia como humano só pode ser compreendido do ponto de vista simbólico. Os traços de humanidade são constituídos nas relações sociais mediadas pela linguagem e pela significação. A inserção da criança no mundo, desde o seu nascimento, caracteriza-se pelo envolvimento rico e diversificado com objetos culturais, estes constituídos de conhecimentos, saberes, instrumentos, práticas diversas, modos de ser, de se compreender e de viver a vida em sociedade. A vida humana inicia-se na corrente viva da linguagem, por meio de carícias e ternas palavras, sussurradas aos ouvidos do recém-nascido.

A vida humana, assim, apresenta-se revestida e inscrita em simbolismos e significações que, genericamente, são denominadas cultura imaterial. Nesse universo, a educação - formal ou informal - salienta-se como uma das mais proeminentes formas de significação a qual todos os indivíduos devem ser submetidos - exigência para se constituírem em suas individualidades e forjarem suas diversas maneiras de sociabilidade.

A Escola é um dos lugares da cultura e, mais especificamente, o lugar de apropriação das valorizadas significações historicamente produzidas pela sociedade que, em sua especificidade, recebe o nome de conhecimentos escolares. Pode-se dizer que aprender e formar-se é apropriar-se dos signos. O início formal começa com o que se denomina de Alfabetização, que é, basicamente, a aquisição e domínio da tecnologia da leitura e da escrita. Ressalta-se que, mais recentemente, adotou-se em todas as escolas públicas o conceito de letramento que, de forma breve, significaria uma "alfabetização" mais ampliada, não mais restrita apenas à aquisição técnica do código (Soares, 2010).

Neste trabalho, tem-se por objetivo apresentar o resultado do que chamo de pequenos exercícios poéticos realizados numa classe de Educação de Jovens e Adultos, cujo guia foi o desejo de configurar a leitura literária como instância de experiência, desenvolvimento intelectual, fruição afetivo-emocional e prazer estético.

A opção por ler poesias, provocar o envolvimento e a inter-relação com o material estético, traz como fundamento teórico a perspectiva histórico-cultural do desenvolvimento humano. Vigotski (2000a; 2000b), um dos estudiosos dessa corrente, atribui papel fundamental à linguagem como instrumento psicológico por excelência para a constituição das funções psicológicas superiores. Para ele, a palavra é o signo mais importantes, pois é por meio dela que o indivíduo se apropria das significações sociais, dos modos de ser, de atuar, de sentir e da cultura.

Vigotski (2004), do ponto de vista teórico-metodológico, recomenda que, ao se estudar um evento, faça-se isso em suas condições concretas de produção. Ou seja, deve-se estudar um fenômeno, um fato, um acontecimento, no momento de seu acontecer, em seu instante dinâmico. Só assim o pesquisador será capaz de apreender os indícios, as evidências que são se dão a ver e que assim podem ser registrados.

Inspirado nessa abordagem, por algum tempo participei de atividades didáticas e pedagógicas em classes de Educação de Jovens e Adultos (1 $1^{\mathrm{a}}$. e $2^{\mathrm{a}}$. Etapas), em Primavera do Sol ${ }^{1}$ - bela e próspera cidade fincada no interior do estado de São Paulo, movida pela riqueza arrancada de seu imenso mar de canaviais. Distante do centro, o Bairro dos 
Arvoredos, em sua topográfica beleza, em ruas sinuosas e ladeiras, muitas ainda de barro e lama, nos dias de chuva, reunia moradores de diversas periferias - como me relataram os alunos -, ali congregados, certamente a contragosto, como resultado da racionalidade técnica e higiênica de planejadores e urbanistas, com suas éticas de "invisibilizar" a pobreza e os excluídos dos bens materiais.

Como professor, auxiliava a professora no planejamento e na execução das atividades didáticas; como pesquisador, anotava, em Diário de Campo, os acontecimentos interativos envolvendo a professora, eu, os jovens e os adultos. Registrava, em minúcias, seus comportamentos, atitudes, gestos, as palavras enunciadas; dava atenção aos movimentos corporais dos mesmos; aos olhares, aos semblantes, às alegrias e tristezas ali manifestados.

Para organização, sistematização e análise dos dados, optei pela narrativa, por considerar como adequado para apresentar os sujeitos na riqueza e na diversidade de suas singularidades, dadas a ver nas dinâmicas interativas em que estavam inseridos. A narrativa, assim, permitiria dar visibilidade às entonações verbais, não verbais, corporais, ao tempo do acontecimento, ao movimento interativo em que os sujeitos, em intersubjetivos afetamentos recíprocos, iam-se deixando entrever.

Ao configurar esses sujeitos como personagens de minhas narrativas, busquei apreender a complexidade das inter-relações - afetivo, emocionais, cognitivas, estéticas - que se constituem no contexto da sala de aula, tendo o conhecimento como importante mediador. A narrativa, no entanto, como instrumento acadêmico de textualização, não deixa de situar esses eventos particulares na interconexão social e coletiva, na universalidade da condição humana, que se inscreve no movimento ininterrupto entre o plural e o singular.

Na reflexão bakhtiniana, o registro dos eventos e a atenção às singularidades não implicaria considerar que cada evento seria explicado por si mesmo e nele próprio se reduziria: dado o fato de que cada evento pertence a uma teia indissociável de outros eventos, "todo evento somente encontra sua completude nas remessas que faz a seu exterior" (Geraldi, p. 3). Ou seja, os eventos se produzem em sua singularidade e, ao mesmo tempo, em sua inelutável articulação com o movimento da totalidade histórica.

A narrativa, como uma obra em polissemia e polifonia ${ }^{2}$, evoca-me Mello Neto (1994) e leva-me a dizer que, o que tecemos, embora não seja "em grosso de tais partidas", mas "a retalho, é de qualquer forma, vida [!]". Ou vidas que se mostram, em suas complexidades e singularidades, nas práticas escolares, experimentadas em dinâmicas de intersubjetividade e interdiscursividade.

No tópico a seguir, trago algumas reflexões sobre como pensar em desenvolver o gosto pela leitura. Como despertar, cultivar, promover o prazer pelos textos escritos se, na fase inicial de aquisição dessas habilidades, as crianças convivem, diariamente, com uma pedagogia e uma didática que se utilizam de conteúdos desprovidos de significados, posto que a busca máxima é a decodificação/codificação? 


\section{0 gosto à leitura literária como algo a ser aprendido}

Especialmente entre os educadores, observa-se um amplo movimento em favor da construção do gosto pela leitura. No dia a dia do ambiente escolar ouvimos, quase sempre, reclamos, como: "as crianças não gostam de ler"; "os jovens não gostam de ler". Avolumamse os escritos acadêmicos sobre a contínua resistência à leitura, principalmente a literária, bem como a nítida sensação de que crianças e jovens estariam preferindo outros suportes midiáticos em detrimento do material impresso. Há, ainda, uma grande esperança de que a escola seja, de fato, um lócus de formação de leitores.

A escola, por sua vez, vem se mostrando falha ${ }^{3}$ nessa tarefa que lhe é atribuída, pelo menos do ponto de vista do ideário pedagógico e da produção de escritos acadêmicos sobre o tema (Dadico, 2017; Formiga; Inácio; Barbosa, 2015; Tauveron, 2014). É certo, claro e está normatizado - nas diretrizes educacionais - que a função do ensino fundamental (do $1^{\circ}$ ao $5^{\circ}$ Ano) é a alfabetização/letramento: a aquisição das habilidades de leitura e escrita, bem como determinadas formas de se expressar usando a escrita, em conformidade com a Base Nacional Comum Curricular (BNCC/MEC).

No entanto, para essa sua missão inicial de formação, a escola, com raras exceções, tem se feito de práticas que tomam a leitura e a escrita como meros processos de decodificação e codificação (Smolka, 2001). A leitura não é explorada enquanto fruição de significados e de sentidos. Alfabetizar - ensinar a ler e escrever - se constitui de procedimentos marcadamente mecânicos, dando-se pouca margem para a compreensão e a interpretação significativa dos textos disponibilizados às crianças (se disponibilizados). Além do mais, grande parte dos textos utilizados são recortes fragmentados que têm como fim último apenas explorar as formas gramaticais (Soares, 2001).

Como, então, pensar o gosto pela leitura? Como despertar, cultivar e promover o prazer pelos textos escritos se, na fase inicial de aquisição dessas habilidades, as crianças convivem, diariamente, com uma pedagogia e uma didática que se utilizam de conteúdos desprovidos de significados, posto que a busca máxima é a decodificação/codificação (Braggio, 2005)?

Com uma prática que privilegia a técnica, os códigos em si mesmos, e não a experimentação da significação dos conteúdos, dificilmente se desenvolverá o gosto, pois esse gosto é sobretudo emoção ou prazer estético. Até desenvolver é um verbo insuficiente, pois pressupõe que já exista o gosto pela leitura em um estágio embrionário. Mas, concebendo-se a leitura como uma prática social e cultural de uma determinada sociedade letrada, pode-se pressupor que o gosto e o prazer pela leitura nascem mesmo no interior das práticas de leituras, realizadas nos ambientes cotidianos dos sujeitos e na escola.

Assim, compreendendo a leitura como uma prática exclusiva de uma sociedade letrada, há que se ter como fundamento básico que ensinar e aprender a ler significa, sobretudo, a criação, consolidação e expansão do gosto. Primeiro, impõe-se considerar que o gosto não é um dado natural e genético. Necessário é superar o senso comum de que todo mundo tem seu gosto - isso não é verdade. O gosto é aprendido e ensinado, seja nos convívios dos indivíduos em suas diversas práticas culturais e sociais, seja na especificidade da formação escolarizada, 
como o lócus de apropriação sistemática de conhecimentos, técnicas, práticas, modos de ser, agir, pensar, sentir e gostar (Bitar, 2013; Vigotski, 2000a).

A escola, em sua acepção moderna, como fruto das ideias iluministas e das necessidades de formação de mão de obra demandadas pela nascente formação capitalista de produção, assume o objetivo de formar os indivíduos em seus diferentes aspectos: cognitivos, instrumentais, sensíveis etc. No entanto, sobressai desse ideário, em termos de valorização social e pedagógica, a formação do indivíduo dentro da racionalidade técnica: formar significa, em termos lato, a preparação do indivíduo para o exercício de funções, tarefas e papeis dispostos no universo de fazeres do capital (Carnoy, 1990; Ponce, 1990; Tamariti, 1999).

A valorização social da leitura, no atual paradigma hegemônico de educação, é centrada sobre conteúdos técnicos, pragmáticos, instrucionais, e não sobre abordagens que visem ao cultivo de aspectos formativos relacionados à arte, ao sensível, ao estético. É a leitura técnica, conteudística, que se assume como valor social e escolarmente perseguido e normatizado em documentos e diretrizes oficiais. Depreende-se daí que a busca da aprendizagem do sensível, do cultivo à apreciação e do gozo do estético apresentam-se como objetivos secundários na ordem formativa para o capital. Assim, ao centrar-se a interpretação textual apenas na valorização dos sentidos das estruturas linguísticas, desconsiderando-se os aspectos metalinguísticos, perde-se "[...] a oportunidade de ressaltar que a função desses é provocar determinados efeitos estéticos sobre o leitor." (Goulart; Trindade, 2013, p. 127).

Pode-se supor que o estético, o belo e suas formas de fruição não possam ser vistos fora de um paradigma social, cultural e econômico, nos quais os bens simbólicos, bem como os materiais, também são apropriados de formas diferenciadas pelas classes sociais. $\mathrm{O}$ valor estético de determinados objetos simbólicos está fortemente atrelado a questões de posses de bens materiais e como objeto exclusivo de fruição das classes ricas e/ou ditas de fina formação cultural. Para Ginzburg (2004, p. 3), “[...] na perspectiva de Roberto Reis, é necessário discutir por que em nosso cânone há poucas mulheres, quase nenhum não-branco e muito provavelmente escassos membros dos segmentos menos favorecidos da pirâmide social".

Concluindo essas reflexões, considero ser importante, no contexto da prática da leitura literária escolarizada, reconhecer que a criação do gosto estético pressupõe um longo cultivar da sensibilidade dos indivíduos a determinados objetos culturais. É necessária a compreensão de que não se amplia o gosto pela leitura literária sem um esforço social para se constituir subjetividades estéticas. Isso exige enfrentamento ao paradigma educacional e formativo sob a ordem do capital, que tem como diretriz o treino de habilidades e competências técnicofuncionais à produtividade. Ou seja, nos diversos níveis de ensino, impor-se-ia a mudança de uma concepção de formação de um leitor decodificador, escravo de monolítica aprendizagem de estruturas linguísticas, para a valorização de um leitor criador, em busca da plurissignificação, da metalinguagem, dos sentidos que a criatividade e a imaginação suscitam ante o objeto estético.

A seguir, faz-se uma reflexão sobre o desafio que a escola enfrenta para promover uma educação literária num momento em que se convive em um jogo global, centrado na indústria 
capitalista de produção em massa, com diversas formas de objetos culturais competindo entre si como fornecedoras de gostos e se insinuam como forjadores de prazer e experiências emocionais e estéticas.

\section{A formação do/a leitor/a e as novas formas de objetos estéticos}

Nos tempos contemporâneos, as agitações da vida, a intensa dinâmica social, movimentada e popularizada em diversos suportes midiáticos, digitais, impressos, provocam a emergências de novos gostos e subjetividades. Ou seja, pensar o gosto significa também pensar esse gosto situado em um tempo histórico. $\mathrm{O}$ gosto pode ser entendido como criação cultural, industrial, tecnológica e, ao mesmo tempo, como submetido a um processo de aprendizagem formal ou cotidiana, que vai se fazendo ao sabor das relações espontâneas que o sujeito experimenta com os diversos produtos culturais. Diria eu que o gosto, por isto ou aquilo, teria seu "protonascimento" no seio de maternas, suaves e cálidas palavras, que em murmúrios chegam aos ouvidos da criança.

Em ternuras, necessidades, exigências materiais, simbólicas e culturais, os gostos vão se configurando como um fato social, histórico acontecimento dialético, em ininterrupto movimento.

Se atualmente a preocupação volta-se para a construção de uma maior valorização de um objeto cultural, como o livro impresso, essa preocupação configura-se dentro de um jogo global, em que diversas formas de objetos culturais apresentam-se como fornecedores de gostos e se insinuam como forjadores de prazer, experiências emocionais e estéticas.

Assim, o que se apreende, social e culturalmente, é que a ideia de formação, consolidação e cultivo do gosto à leitura literária nasce no interior de um mundo cultural, profundamente competitivo, dominado pela tecnificação. Dessa tecnificação sobressai - entre outros objetos, assumindo-se como portadores de uma estética - a massificação de uma literatura de consumo rápido que atinge crianças e jovens indistintamente.

Desse modo, o desafio de criação do gosto literário passa pela compreensão de que o suporte livro, como objeto artístico, não detém mais o monopólio de ser visto como único e principal objeto de conhecimento, entretenimento, objeto artístico, fonte de fruição do prazer emocional e estético. $\mathrm{O}$ ciberespaço, como uma gigantesca realidade virtual, encapsulou em seu entorno novas formas de objetos estéticos e, por consequência disso, vem produzindo, a cada momento, a emergência de gostos diversos, de formas variadas de acesso aos conhecimentos, entretenimentos e prazeres, ampliando-se, assim, as experiências subjetivas e estéticas dos indivíduos.

Alicerçado na indústria cultural, o ciberespaço se constitui também na disseminação de cibergostos, fazendo surgir formas estéticas que competem com o conceito canônico de estética e de belo. Assim, a arte literária, como uma das formas de discurso, ganha adversários que possuem mais recursos de massificação. Nessa luta, o texto literário - nomeadamente o impresso - enfrenta uma batalha com armas desiguais para se fazer gostar e se impor pelo valor estético da palavra (Pereira; Brunieri, 2018). 
Dentro dessa perspectiva de competição desigual entre diferentes produtos culturais que se insinuam como objetos estéticos, de prazer e emoção, a criação do gosto pela leitura literária, além das demandas estruturais, exige arranjos que disseminem o texto escrito como fonte de prazer e emoções. Isso significa que o desafio é criar espaços e ações que transformem o texto literário em um movimento de sentidos e significações que afetem os sujeitos em suas subjetividades. Em outras palavras, que a inter-relação obra-leitor seja experimentada como fruição e emoção estética.

A escola, como lócus de formação, precisa - e essa é a exigência - se transformar em um espaço que acolha uma prática literária que suscite o prazer, o gosto, a emoção. Para isso, é necessário considerar que a aquisição do gosto por um dado objeto cultural passa por um longo processo de aprendizagem e de experimentação. A leitura não é um ato simples, mas demanda, da parte do leitor, que domine dimensões imprescindíveis à decodificação: domínio linguístico, conhecimentos prévios e culturais para ir além da superfície do texto. Esses domínios dependem de aprendizagens sistemáticas longas.

A escola pode se constituir no lócus dessa formação, à medida em que tome para si esse importante objetivo de criar, desenvolver e consolidar o gosto pela leitura e, por consequência, a fruição do prazer da experiência estética. A compreensão, decorrente da interpretação, exige do leitor investimentos cognitivos, informativos, experiências anteriores. Um texto, não somente o literário, impõe difíceis e complexos desafios ao leitor para ser compreendido (Jouve, 2002). Assim, a constituição de uma subjetividade leitora, apreciadora da obra literária requer aprendizagem, prática e aquisição de conhecimentos básicos.

O sujeito, pois, se faz leitor, aprende a ser leitor quando imerso no jogo da significação e dos sentidos compartilhados. O entendimento, a compreensão, são vistos, nesta discussão, como produzidos nas relações intersubjetivas e interdiscursivas. Nessa perspectiva, não teríamos a figura de um "leitor individual", mas de um leitor que se constitui, constrói-se no jogo interativo, interpretativo, polifônico e polissêmico em expansão e circulação entre os envolvidos. Instabilidade de significações e sentidos se instauram e fazem fluir formas diversas de suscetibilidades e fruições, emoções estéticas.

Há uma espécie de senso comum, que se assume como verdade científica ${ }^{4}$, bastante consolidado e que faz parte do ideário ideológico e didático, no cotidiano escolar, de que a reflexão, o entendimento, a compreensão são funções cognitivas que afloram unicamente como resultados da demanda de esforços individuais. Essa ideia demarca a postura do mediador na relação aluno e conhecimento, na qual aquele espera, sempre, que o entendimento e compreensão sígnica parta, inevitavelmente, do aluno.

Conjetura-se, no entanto, que a reflexão não ocorre, unicamente, como um processo individual e solitário, mas como decorrência de interações professor-aluno-conhecimento. A reflexão e o entendimento nascem no contexto dessa dialogia intersubjetiva e interdiscursiva. É/São o/os outro/outros que provoca/provocam a reflexão e a compreensão - seja o professor, com seus conhecimentos consolidados, suas experiências pedagógicas e didáticas, suas vivências de mundo, sejam os conhecimentos, como alteridades simbólicas.

Concluindo este tópico, pode-se dizer que formação à leitura literária, tendo o objeto livro (impresso) como valor estético, não pode desconsiderar a dinâmica que a tecnologia 
vem assumindo na produção e criação de novas formas de objetos estéticos, dando aos indivíduos uma diversidade de formas de entretenimento e lazer. Um outro aspecto que essas reflexões trazem é não deixar de considerar que a leitura literária está inserida num jogo simbólico poderoso e competitivo, no qual diversos produtos se assumem como portadores de fruição do prazer estético. A escola, na contemporaneidade, enfrenta um grande desafio em colocar a leitura literária como protagonista em um contexto dominado pela produção de massa do sistema capitalista.

A narrativa a seguir se constitui como exemplo de enfrentamento desse desafio, que professores e professoras devem levar a cabo em suas práticas no contexto escolarizado, disponibilizando a leitura literária em diferentes formas e estratégias didáticas e pedagógicas.

Assim, convido a cara leitora e o caro leitor a seguirem comigo nesse itinerário em que jovens e adultos experimentam, na relação com os textos literários, momentos de fruição do prazer estético.

\section{Leitura literária: exercícios poéticos e fruição estética}

O terminal rodoviário da cidade de Primavera do Sol foi, por muito tempo, o nosso ponto de encontro, onde pegávamos, sempre por volta das 17 horas, o ônibus que nos levava ao distante bairro Bosque dos Arvoredos. Era, também, nosso ponto de chegada, às 22 horas, com certa regularidade. Nesse trajeto, de idas e vindas, com uns 40 minutos de duração, aproveitávamos para dialogar sobre como criar alternativas didáticas e pedagógicas para contemplar aquela classe de jovens e adultos em sua diversidade e diferença: os jovens, adolescentes - meninas e meninos -, com seus comportamentos irrequietos, falantes, sempre arengando uns com os outros; e os adultos - mulheres e homens - mergulhados em seus silêncios, às vezes cabeça baixa, a mirar o caderno, às vezes apenas observando os jovens em suas tagarelices.

Eu sempre chegava ao terminal primeiro. Naquele dia, ainda sob restos de Sol primaveril e gélido vento, observei a professora Iracy chegando, passos lentos. Ao aproximar-se, percebi-a um pouco diferente. Parecia muito abatida - a fisionomia -; em expressão de cansaço se mostrava; olhos fundos e avermelhados, via-se. Ela que, mesmo vindo de dois turnos de trabalho em outra escola, sempre demonstrava alegria e sorriso largo: "Ah, hoje estou sem condições de dar aula. Estou indo porque não gosto de faltar", disse-me ela, em entristecida tonalidade.

Já em sala, a professora informa aos alunos - Turma $2^{\text {a }}$ Etapa - que a aula é por minha conta e vai sentar-se no meio deles, com seu entristecido semblante. Iniciei a aula de acordo com o que havíamos combinado no dia anterior. Cumprimentos iniciais. A explicação do que iríamos fazer: "Hoje, vamos ler poesias". Algumas informações sobre Carlos Drummond de Andrade, ressaltando a sua importância na história literária do país, para começar. Os alunos ouviam-me atentamente. Em seguida, distribui a eles uma folha com poesias. Aprumei a voz. A professora acompanhou-me, no pedido de atenção. Silêncio na sala. Todos com as folhas nas mãos, comecei a leitura, em voz alta, pausadamente: “Quadrilha: João amava Teresa que 
amava Raimundo / que amava Maria que amava Joaquim que amava Lili...”. Parei, observei a turma, que me olhou e explodiu em gargalhadas.

À minha frente, pergunta-me uma senhora aluna, em seus aproximados 45 anos: "De qual nação você é?”; "Como assim?”, pergunto-lhe, "Sou da nação brasileira..." "Não..., isso eu sei...", interrompe-me ela; "Sou do Norte, de Belém, Pará"; “Ah, sei, de Belém do Pará!”, murmura. "Por quê?", "Porque o senhor fala muito bonito", disse em largo sorriso. Olhem ela! Se dando a ver em afetos poéticos. Sempre pontual, por volta das 18:30 horas, a via descer a íngreme rua ladeirosa que dava acesso à escola. Esguia, vestido limpo, passado, longos cabelos amarrados; cadernos aprumados nos braços a lembrar uma adolescente colegial. "Lavo, passo, cozinho e cuido de duas crianças numa casa lá no centro; acordo às 5 da manhã", disse-me, num daqueles friorentos dias em que eu ajudava as professoras a servir um também já frio capuccino com pão dormido, no intervalo das aulas.

Refiz o fôlego. Aguardei o silêncio da turma e convidei: "Vamos ler outro poema de Drummond, No meio do caminho: "No meio do caminho tinha uma pedra...". Procurei ler com voz alta, ritmada, dando ênfase e sonoridade aos versos. Alguns apenas ouviam e outros acompanhavam-me na leitura. Ao final, observei, nas expressões, sorrisos, indícios de que a poesia estava agradando e de que a dinâmica de leitura utilizada provocara algum estranhamento e emocionais afetamentos. Em olhares moviam-se pela sala em direção aos colegas, como que consultando um ao outro.

Distribuí uma segunda folha com o poema: Poema de sete faces: "Quando nasci, um anjo torto / desses que vivem na sombra/ disse: vai, Carlos! Ser gauche na vida...". "Mais folha, professor?!", surpreende-se Ander; "Mais folha, hoje a aula é só poema do Drummond". Os alunos comentavam, entre si, alguma parte do poema, mostravam a folha ao outro, apontavam algum ponto que lhes despertara interesse. Pedi silêncio e continuei mais uma leitura: "As casas espiam os homens / que correm atrás das mulheres". Algumas risadas na sala. "O bonde passa cheio de pernas: / pernas brancas pretas amarelas / para que tanta perna, meu Deus, pergunta meu coração...”. Muitas gargalhadas. Ander, 15 anos, e outros alunos à minha frente, explodiam em incontidos risos, sobretudo diante do verso: "para que tantas pernas, теи Deus".

Lia e observava a reação afetiva e emocional da turma. Os semblantes refletiam satisfação. Alguns tentavam acompanhar-me na leitura: "Mundo vasto mundo, / se eu me chamasse Raimundo / seria uma rima, não uma solução...”. Novos risos, principalmente pelo Raimundo. "Você escolheu esse poema porque tem o seu nome nele, não é?", brinca a professora.

Concluí a leitura. "Gostaram?”. Confirmaram balançando a cabeça positivamente. A pergunta era desnecessária. Havia um clima de satisfação na sala. Muitos sorrisos, um e outro aluno arriscava algum comentário em voz alta sobre algum verso. Conversavam animadamente entre si, examinando as folhas, relendo para o colega. A interlocução tomava os poemas como tema. Ou dito de outra forma: os poemas mobilizavam, sustentavam e expandiam a interlocução entre os jovens e adultos. A obra literária produzindo seu efeito estético, prazer, emoção. 
Cristiano, 14 anos, muito tímido, introvertido, fala baixa, mansa, lia com o queixo quase em cima da folha. Sorriso contido, concentra-se no texto assim que a leitura iniciava. Lúcia não economizava comentários com um colega ao lado. Isabel, Aldo e a própria professora Iracy também faziam comentários entre si. Telma, uns 22 anos, com seus dois filhos, um de colo, dormindo nos seus braços, e outro, um pouco maior, de uns três anos, dormindo sobre duas carteiras, acompanhava atentamente a leitura, meneava a cabeça, fazendo sinais positivos, em sorrisos indiciados. Nelma, em seus 40 anos, à minha frente, sorria. Marlindo, 15 anos, mantinha-se na carteira, apenas ouvindo a leitura que eu fazia. Ângela, uma aluna magrinha, cabelos compridos, escorridos, outra das mais introvertidas, de pouco sorrisos, ouvia atentamente. Outros alunos, cujos nomes eu ainda não dominava, participavam também, comentando as poesias, relendo o texto, acompanhando as risadas dos colegas.

Seu Raimundo, negro, a indiciar uns 50 anos, pedreiro, em calosas mãos, rabiscava, à margem das folhas, algumas figuras como a ilustrar os poemas. Nos momentos do lanche, às vezes expressava a mim seus sentimentos de satisfação com as leituras poética. Lembro-me, em admiração, daquele dia em que a professora e eu levamos a turma para o pátio com o objetivo de organizar um "Mural" com as produções dos alunos e alunas. E ele se fez presente, entre os alvoraçados adolescentes, entregando à professora, duas páginas com poesias e as ilustrações ao lado. Para a poesia No meio do caminho tinha uma pedra, ele desenhou um riacho, pedras de diferentes tamanhos aprisionando o curso da água; à margem arbustos e árvores deitavam sombra sobre uma criança em atitude de observação. E ele ficou a apreciar, assim como os outros e outras, a sua produção afixada, lá no alto, no Mural Escolar.

Depois de fazer alguns comentários sobre os poemas e de espontânea interlocução com alguns deles, entreguei mais uma folha e, novamente, de forma divertida, ouço Ander perguntar, surpreso: "Mais folha?!"; "Mais folha!!", respondo-lhe. Ele sorria, falava, lia, remexendo-se e contorcendo-se na carteira.

Lira do amor romântico é o próximo. "Vamos fazer uma outra dinâmica agora?", convido-os. "Dinâmica?!! ... Dinâmica?!!", surpreendem-se. Explico-lhes o que é dinâmica. Explico-lhes, ainda, que um poema é composto por versos e estrofes. Cada estrofe contém certo número de versos. Cada linha é um verso. Mostro-lhes os "bloquinhos" em que está dividido o poema que eles tem em mãos. Desenho no quadro, as linhas, as estrofes.

A dinâmica era a seguinte: eu lia os primeiros versos de cada estrofe, e eles somente o último verso, que era a resposta do "peixinho". Começamos, pausadamente: "Atirei um limão n'água / e fiquei vendo na margem / os peixinhos responderam...". E os alunos: "Quem tem amor tem coragem". A leitura do poema, composto de 20 estrofes, prosseguiu entre risadas e comentários. Às vezes, apenas alguns alunos respondiam. "Vamos gente, não comeram feijão hoje? Vamos ler, vamos!!”, estimulava a professora. Os alunos se esforçavam e liam mais alto. Às vezes alguns gaguejavam e o sentido, a rima e a sonoridade ficavam truncados. "Vou repetir de novo". E eu lia novamente toda a estrofe, incluindo a parte dos alunos, com ênfase e explorando os aspectos literários.

Procurava, assim, explorar o ritmo do poema, acentuando a rima, buscando chamar a atenção não somente para o conteúdo do poema, mas para melodia, para a beleza da 
sonoridade das palavras. E essa forma de ler parecia produzir efeitos. Os alunos me observavam, lançavam-me olhares de curiosidade pela forma como lia. Lembro-me que eles leram, sem ênfase e sem as marcas de pontuação "Se é amor deixa disso". "Vou repetir: Atirei um limão n'águal foi tamanho o rebuliço/ que os peixinhos protestaram: / Se é amor, deixa disso". Li a primeira parte desse último verso com bastante ênfase e fiz uma pausa para ler o final: "Se é amor!!! [pausa breve] deixa disso!!!". Telma lançou-me um olhar arregalado, de curiosidade, como se na leitura anterior não tivesse se apercebido do sentido do que lera conjuntamente com os colegas. "Tu me terás esquecido", leram os alunos, "Tu me terás esquecido?", "Olha o ponto de interrogação", alerta a professora. E relemos de novo, em atenção à observação didática da professora.

A leitura chegou ao final em um clima de prazerosa descontração. Concluída essa parte, era chegado o outro momento: o de trabalhar a escrita. Ou seja, fazer aquilo que, para Snyders (2001, p. 135), é o "[...] exemplo de alegria provocada pela alteridade da escola, a escola como mundo distinto do mundo da vida: a redação [...], palavras, palavras, pois nada é mais vivo que as criações literárias".

Sugeri que compusessem um poema, com a seguinte orientação: criar, adaptar versos do autor, fazer paráfrases e montar um texto em um exercício de trabalho coletivo: cada um deveria contribuir com ideias próprias ou apropriadas dos poemas. A arte de se insinuar como escritor: brincar com os poemas, desarrumá-los, destecê-los e tecê-los novamente com os arranjos afetivos dos alunos, investidos de autores.

O objetivo da atividade era possibilitar maior interação com o texto, propiciar espaço para a interlocução dos alunos com os poemas e dos alunos entre si, mediados pela leitura. $\mathrm{O}$ texto produzido seria, então, o resultado daquilo que os poemas significaram; do que produziu sentido e os afetou emocional, afetiva e esteticamente.

Os dois grupos, coordenados por mim, produziram textos a partir dos poemas que lhes chamaram a atenção, fizeram paráfrases, apropriaram-se de parte de versos para montar estrofes; destacaram versos que os haviam tocado afetivamente. O grupo, coordenado pela professora Iracy, fez algumas paráfrases do poema Lira do amor romântico.

Ao final, fiz a leitura para a turma de todas as produções, enquanto Josué, 18 anos, extrovertido (mas bem individualista - não gostava de trabalhar em grupo com outros adolescentes porque "só falavam e escreviam besteira"), puxava as palmas: "Vamos aplaudir!!!". E, imediatamente, todos aplaudiam com entusiasmo a criação de cada grupo. Terminei a leitura, sob coletivas gargalhadas e emocionais palmas. A seguir, a produção do grupo coordenado pela professora Iracy,

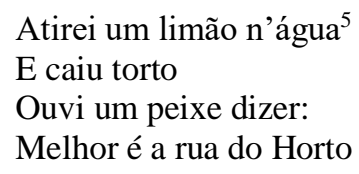

Atirei um limão n'água

Como faço todo ano

Senti que os peixes diziam: 
Chega logo o fim do ano.

Atirei um limão n'água

Como um vidro de perfume

Em coro os peixes disseram

E lá vem outro cardume

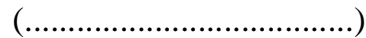

Atirei um limão n'água

Ele afundou uma canoa

Não ligaram os peixes

Levaram numa boa

Atirei um limão n'água

Para achar o meu amor

Os peixes disseram

Não me levem por favor

Atirei um limão n'água

Atirei um limão n'água

Mas depois me arrependi

Cada peixe que matei

Me lembra o que sofri

E fiquei vendo na margem

Os peixinhos responderam:

Vai com Deus, boa viagem!

Fui para casa me consolar

Pois acabaram meus limões

Fiquei ouvindo

O CD: Rio Negro e Solimões.

[Tive um sonho estranho

E também muito engraçado

Sonhei que o presidente estava na enxada

E os trabalhadores na sombra dando risadas $]^{6}$

A possibilidade de produzir um texto provocou prazer, envolveu os sujeitos no ato de criação, alimentando-se do contentamento suscitado pela leitura inicial dos poemas, leitura essa que servia de referência à imitação e à inspiração criadora.

Depois dos entusiasmados aplausos, fiz alguns pequenos comentários sobre o desenvolvimento da atividade. Encerrei a aula, citando de cabeça, parte do poema Resíduo, de Drummond: "De tudo fica um pouco...". Adaptei alguns versos mencionando a situação da sala, nome dos alunos e alunas: "Fica um pouco da alegria dos alunos / Um pouco do gosto pela poesia...". Uns e outros e outras, espontaneamente, entraram na brincadeira, trouxeram a "sua palavra" para o centro da "roda", completando a minha paráfrase, acrescentando-lhe palavras ou os nomes de colegas. Era a palavra em movimento, na corrente viva da linguagem, suscitando e mantendo a interlocução. Poder-se-ia dizer, didaticamente 
(porque estamos no terreno do escolar), que a leitura literária se mostrou em seu objetivo como arte: fruição estética, interação de subjetividades obra e seu leitor/leitora, ou leitores e leitoras, nesses exercícios.

Em estado de alvoroço, alunas e alunos deixaram a sala em sorrisos e emocionantes estados d'alma. "A AULA DE HOJE FOI MUITO BOA!!!”, gritou bem alto Isabel, uns 40 anos, já de costas para a sala, no que foi seguida por outros alunos, fazendo ecoar, aos outros, o seu imenso contentamento.

As gargalhadas, os semblantes de alegria, as manifestações verbais elogiosas, a atenção dos alunos, sua disposição para realizarem a atividade de escrita, a escuta atenta aos dizeres e à leitura dos textos dos colegas me indiciavam que haviam experimentado uma relação prazerosa com a leitura e com o ato da escrita. Na produção textual, apropriando-se, parafraseando o autor, produziram significados e sentidos que os afetaram emocional, esteticamente.

Como destaca Snyders (2001, p. 169), a admiração (evidentemente) não se impõe, mas "[...] para haver uma chance de que os alunos admirem o escolar, é preciso que o escolar apresente algo de admirável”. A arte da palavra foi o admirável naquele encontro: o ritmo dos poemas, a sonoridade das rimas, o jogo de sentidos.

Colocar os alunos diante da linguagem escrita, da leitura em voz alta, foi uma das muitas formas possíveis de "[...] pensar o ensino e a aprendizagem da leitura [e da escrita] como a abertura do sujeito à linguagem." (Larrosa, 2000, p. 13). Como bem analisam Vigotski (2000a) e Bakhtin (1997), a linguagem é constitutiva do sujeito, é pela linguagem que o sujeito se apropria do mundo e da cultura e, por conseguinte, constitui-se em sua humanidade, singulariza-se. Assim, "[...] somente o combate das palavras ainda não ditas contra as palavras já ditas permite a ruptura do horizonte dado, permite que o sujeito se invista de outra maneira, que o eu seja outro." (Larrosa, 2000, p. 40).

Em efeitos estéticos, os alunos ouviram, leram, trabalharam, fizeram-se criadores, vivenciaram e compartilharam sentidos e significados, vivenciaram a confiança no grupo. Foram, ao mesmo tempo, autores e audiência. Escreveram, não apenas para si mesmos ou para a professora e o professor. Foram lidos e ouviram seus próprios textos. Na linguagem e pela linguagem, experimentaram diferentes funções e possibilidades do ato de ler e de escrever e, também, diferentes formas e possibilidades de se apresentarem como alunos e como usuários da escrita. O aprendizado, conforme destaca Vigotski (2000a), tem um papel crucial no desenvolvimento da consciência do indivíduo ao possibilitar-lhe o acesso a outros saberes, a outras práticas, a outros modos de viver os lugares sociais.

Trabalho intelectual e desenvolvimento cognitivo articulados, de forma indissociável, com a fruição da alegria materializada em palavras e gestos, dando-nos a ver que o afetivo não vem de fora, mas acontece mesmo é na relação entre os sujeitos e o conhecimento, na interação social, na intersubjetividade. E, nesse caso, na intersubjetividade entre obra estética e seus leitores e leitoras. "Minha' escola quer e acha possível uma continuidade entre a vivência dos alunos, seus valores, gostos, expectativas." (Snyders, 2001, p. 139).

A professora, como os alunos, mostrou-se em contentamentos. Observei-a, na saída, ainda à porta da sala. Tinha um sorriso largo. "Foi muito bom, muito bom mesmo!!!", repetia 
enfática. Na parada, enquanto aguardávamos o ônibus, ela voltou a fazer comentários, destacando a relação afetivo-emocional, os efeitos estéticos da obra literária que acabara de viver e que provocara nela uma significativa mudança em sua subjetividade: "Foi bom até para mim, melhorei da minha dor de cabeça. Você viu como eu estava? Agora estou melhor, fiquei rindo lá no grupo dos meninos... me divertindo, que melhorei...”.

Parece-me que a leitura literária levou a professora a experimentar, em emoções de prazer, sua própria catarse. De fato, ela não mais parecia a pessoa que eu encontrara na parada do ônibus muito abatida pelo falecimento de uma colega de trabalho, com dor de cabeça, olhos murchos. À entrada da escola: "Você sabe como a gente fica quando bebe, meio zonza? Assim é que estou me sentindo, como se tivesse bebido... Hoje vou ficar sentadinha lá no fundo e você é que comanda a aula", disse-me ela. Mas, com alguns minutos de aula, recobrara o ânimo. Junto aos alunos, acompanhara a leitura, participava, sorria, fazia comentários. Diria eu que os efeitos estéticos da obra de arte agiram modulando as suas disposições subjetivas.

A intenção literária, como uma didática em ação, era, pela poética leitura, possibilitar o acesso à arte, provocar o desejo e suscitar a admiração, pois, concordando com Larrosa (2000, p. 13), a educação literária tem como única virtude "[...] a sua infinita capacidade para a interrupção, para o desvio do real e para a abertura do desconhecido. A iniciação à leitura aparece, assim, como o início de um movimento excêntrico, no qual o sujeito leitor abre-se à sua própria metamorfose".

Encanto. Encanto é uma palavra forte, mas é a que me ocorre para caracterizar o carinho com que os alunos tratavam as folhas com os poemas que eu distribuíra. Com meu pernicioso costume acadêmico de riscar os textos dos livros, na atividade de consulta ao dicionário a partir de palavras cujo significado os alunos desconheciam, tentava marcar algumas palavras desconhecidas e seus significados nas folhas de Lúcia. Ela puxou as folhas mais que rapidamente para si, protegendo seus poemas da ponta de meu lápis: "Não, essas são as minhas! Vou guardar as poesias comigo... Vou copiar todas no meu caderno".

O mesmo aconteceu com Ander. Ao grifar as palavras em suas folhas, imediatamente ele apagava. Cristiano procedeu da mesma maneira e, por duas vezes, perguntou-me, segurando as três folhas com os poemas junto ao peito: "Cê vai levar embora?". A reação carinhosa desses alunos levou-me a considerar sua pequena (senão inexistente) relação com o material impresso. Na Educação de Jovens e Adultos, sem a obrigatoriedade de livro didático, as aulas, rotineiramente, restringem-se à cópia do quadro. Talvez, viesse daí a surpresa de Ander em perguntar-me, a todo o momento: "Mais uma folha?" E de Cristiano: "Cê vai levar embora?" "Cê vai levar embora?"

Como amar o literário? Como gostar da leitura, como apropriar-se dela se, na escola, ela é vivida nos moldes de uma sociedade sem imprensa? Se na escola, o que menos ocorre é a relação do aluno com a escrita em suportes diversos? A formação do gosto é primordial e deve ser construído por meio de experiências positivas, com a identificação de interesses e liberdade de escolhas, como sugere Kramer (1999).

Cristiano escolhera para a composição do poema de seu grupo os seguintes versos: "Quando nasci, um anjo torto / desses que vivem na sombra / disse: Vai, Carlos! Ser gauche 
na vida". Depois me perguntou, apontando a palavra, em sua voz quase inaudível, o que era gauche. Ander ficou fazendo pilhéria com ele por causa dessa escolha. Cristiano sorria, econômico, à brincadeira. "Ó, professor, esse menino aí escolheu esse aqui", falava Ander, apontando a estrofe. Quieto, calmo, introvertido, olhos graúdos, sempre avermelhados, fugazes, identificou-se com essa parte do poema, que parecia dizer um pouco daquilo que ele aparenta ser na sala de aula. O poema o afetou, certamente, pois a ficção não deixa de interagir com a subjetividade do sujeito leitor. Em algum determinado momento, eu soube, por meio da professora e do que ouvi de alguns colegas seus, que o mesmo estava na escola por recomendação do Conselho Tutelar da cidade.

Ander era o redator do grupo em que estava Cristiano. Ele organizava os versos que foram sendo criados/escolhidos/modificados/parafraseados por seus colegas. Muito comunicativo, interagia com todos. Sempre sorridente a mostrar parte do que fora um aparelho de correção dentária. Às vezes chegava com a camisa, a calça, o velho tênis, todos sujo de um amarelo barro. "Ó, professor, trabalho com meu tio, ajudo ele a cavar sepultura, lá", contou-me certa vez, ante minha indagação sobre seus desbotados e gastos trajes. Diziame sempre que não gostava de português, só de matemática. Mas, em suas atitudes, mostrase o mais interessado, participativo e dinâmico aluno da classe. Às vezes, eu também fazia observação na turma da $1^{\text {a }}$ Etapa. E ele ficava, lá na porta, perturbando a professora e a mim com pedidos para eu ir para a sala dele. "Mas rapá, tu gosta de português", dizia-lhe. E ele insistente: "Cê vai pra minha sala?" e, dirigindo-se à professora: "Ei, dona? Deixe o professor ir pra minha sala!". A professora desconversava e eu, depois de uns muitos “amanhã eu vou”, acabava o convencendo a voltar para sala dele.

Agora, como líder do grupo de adolescentes, na atividade, acentuava seus traços de tagarelice e mostrava-se também "mandão" e até "crítico literário", criticando as escolhas dos colegas e, ao mesmo tempo, pedindo minha confirmação. Para seu desgosto, eu sempre o desapontava: "A atividade é para fazer uma composição com os gostos de cada um, Ander". E ele levava numa boa e cobrava eficiência.

“Ó, professor, já terminamos [entregando-me a produção do grupo], agora estou escrevendo só pra mim mesmo". E transcrevia para seu caderno versos/estrofes inteiras que ia selecionando dos poemas de Drummond. Essa atitude de Ander lembrou-me outra observação de Snyders (2001, p. 60) sobre a relação do aluno com a escola: “[...] o jovem leva para a escola a 'genialidade' da qual ela necessita para vir a ser escola de alegria, e as 'carências', que fazem com que ele necessite da escola para buscar mais alegria".

Lembro-me que, alguns minutos após a leitura dos poemas, fui até a carteira de Lúcia, que me chamara para mostrar, em seu caderno, "Quadrinhas" chulas. "Foi uma amiga que me deu, mas não gostei não!", diz, revirando os beiços e sacudindo a cabeça negativamente. "Gostei mais das de hoje". As diferenças entre uma "boa poesia" e outra de "mau gosto" só nos são acessíveis quando conhecemos umas e outras, quando podemos elaborar nossas comparações entre elas e expressá-las. É assim que se forma o gosto: pelas experiências diversificadas com a produção cultural. Porque a experiência é a relação entre conhecimento e a vida humana. É aquilo que nos passa e nos afeta (Larrosa, 1996), e eu acrescentaria que a experiência é aquilo que nos trespassa. A experiência é forjada na articulação de saberes, 
conhecimentos, objetos físicos e simbólicos, vividos e compartilhados, o que pressupõe a mediação intersubjetiva.

\section{Considerações finais}

Os gestos e comentários, como manifestações afetivas dos alunos, indiciaram-me o quanto foram afetados em suas subjetividades pela poesia e me levaram a refletir sobre a necessidade de uma escola que se faça de possibilidades de interação entre os saberes escolares e as vivências e necessidades estéticas, afetivas e cognitivas dos educandos; uma escola na qual estes encontrem as oportunidades concretas para se constituírem como sujeitos históricos, para se apropriarem de saberes e práticas socialmente valorizadas, indispensáveis à sua humanização; uma escola em que tenham acesso a diferentes e diversificadas experiências de leitura, de escrita e de outras linguagens, desenvolvendo-se o refinamento do gosto estético, afetiva e cognitivamente.

Incentivados a enunciar e a compartilhar os sentidos em elaboração, tendo a obra literária como inspiração e mediação, os alunos se fizeram autores, tomando a palavra do outro, recriando-a, fazendo-a sua. Trata-se de estimular e valorizar a elaboração do que o aluno vive e sente, ampliando sua experiência, seu pensamento, sua experiência estética. Nesses exercícios poéticos, mais do que a informação, guiava-me o desejo de configurar a leitura e a escrita como instâncias de experiência e de sabedoria.

Esses exercícios sugerem que a prática da leitura literária escolar deveria, assim, tomar como pressuposto que o gosto decorre das significações e dos sentidos em funcionamento, na corrente viva da linguagem. Isso requer o desenvolvimento de estratégias que trabalhem a leitura numa perspectiva dialógica. Os sujeitos, alunos, em interação com o texto, provocam a produção de sentidos outros, diversos e diferentes, a partir dos muitos e tantos entendimentos particulares, singulares.

Na sala de aula, assim, a aprendizagem da leitura literária deixaria de ser pensada como uma prática individual, isolada, silenciosa, restrita a um sujeito leitor e seu texto, mas deveria ser pensada e experimentada como leitura compartilhada entre alunos. Parte-se da suposição de que a compreensão não é apenas um dado individual, mas que a compreensão de um texto literário pode ser experimentada, ampliada, expandida num jogo de interação entre leitores numa determina classe de alunos.

A compreensão, assim, construir-se-ia na interação intersubjetiva e interdiscursiva, pois a interlocução coletiva provocaria a emergência de entendimentos que, por sua vez, levam à compreensão e significação do texto em circulação. Estariam, então, sendo criadas as condições para a emergência do gosto, do prazer e da fruição estética. Os sujeitos envolvidos experimentando-se em efeitos estéticas ante a obra de arte. 


\section{Notas:}

1. O nome da cidade, bairro, assim como da professora, alunos e alunas foram substituídos por nomes fictícios.

2. Esses termos são discutidos, numa abordagem bakhtiniana, em Amorim (2001).

3. Toassi e Lacowitz (2013) observam que grande parte dos professores não é bem sucedida na tarefa de despertar, nos estudantes, a beleza estética dos textos literários.

4. Refiro-me ao "escolanovismo" e à psicologização do ensino-aprendizagem; abordagens de cunho inatistamaturacionista (Fontana, 1997).

5. A professora se encarregou de passar a limpo a escritura dos alunos e fez a correção ortográfica necessária.

6. Esses versos foram feitos unicamente por Josué - que ficou no grupo dos adolescentes, mas preferiu produzir sozinho, me consultando sempre sobre a grafia correta de determinada palavra, seu significado etc.

\section{Referências}

AMORIM, M. O Pesquisador e seu outro: Bakhtin nas Ciências Humanas. São Paulo: Musa Editora, 2001.

BAKHTIN, M. M. Marxismo e filosofia da linguagem. São Paulo: Hucitec, 1997.

BITAR, N. P. Patrimônio e Dádiva: as baianas de acarajé no Rio de Janeiro. GONÇALVES, J. R. S. et al. (org.). A Alma da Coisas: patrimônios, materialidades e ressonâncias. Rio de Janeiro: Murad X: Faperj, 2013. p. 77-99.

BRAGGIO, S. L. B. Leitura e Alfabetização: da concepção mecanicista à sociopsicolingüísta. 3. ed. Porto Alegre: Artes Médicas, 2005.

CARNOY, M. Educação, economia e Estado: base e superestrutura, relações e mediações. São Paulo: Cortez, 1990.

DADICO, L. Leitura literária, experiência e formação do indivíduo: reflexões a partir da crítica do adorno. Psic. USP, São Paulo, n. 2, v. 28, p. 179-188, 2017.

FONTANA, R. Psicologia e trabalho pedagógico. São Paulo: Atual, 1997.

FORMIGA, G. M.; INÁCIO, F. A.; BARBOSA, S. F. P. Leitura, escola e formação literária: entre práticas e descaminhos. Rev. Principia, João Pessoa, n. 28, p. 169-177, dez. 2015. Edição especial.

GERALDI, J. W. Alteridades: espaços e tempos de instabilidades. Campinas: IEL/UNICAMP, 2003. Mimeo.

GINZBURG, J. Cânone valor estético em uma teoria autoritária da literatura. Rev. de Letras, São Paulo, v. 44, n. 1, p. 97-111, 2004.

GOUlART, A. T.; TRINDADE, V. C. M. O Caráter estético do texto literário na formação do leitor. Rev. ContraPonto, Belo Horizonte, v. 3, n. 4, p. 111-128, 2013.

JOUVE, V. A leitura. São Paulo: Editora da UNESP, 2002.

KRAMER, S. Leitura e escrita de professores em suas histórias de vida e formação. Cad. de Pesquisa, São Paulo, n. 106, p. 129-157, mar. 1999.

LARROSA, J. Literatura, experiência e formação. [Entrevista cedida a] Alfredo Veiga-Neto, jul. 1995. In: COSTA, M. V. (org.). Caminhos investigativos: novos olhares na pesquisa em educação. Porto Alegre: Mediação, 1996. p. 133-160.

LARROSA, J. Pedagogia profana: danças, piruetas e mascaradas. Belo Horizonte: Autêntica, 2000.

MELLO NETO, J. C. de. Morte e vida severina e outros poemas para vozes. Rio de Janeiro: Nova Fronteira, 1994.

PEREIRA, D. P.; BRUNIERI, A. R. S. A experiência literária a partir da fanpage SP Invisível no Facebook. 
Rev. Desafios, São Paulo, v. 5, n. 3, p. 54-69, 2018.

PONCE, A. Educação e luta de classes. São Paulo: Cortez, 1990.

SMOLKA, A. L. B. A Criança na fase inicial da escrita: a alfabetização como processo discursivo. São Paulo: Cortez; Campinas: Editora da Unicamp, 2001.

SNYDERS, G. Alunos felizes: reflexões sobre a alegria na escola a partir de textos literários. São Paulo: Paz e Terra, 2001.

SOARES, M. Letramento: um tema em três gêneros. Belo Horizonte: Autêntica, 2010.

SOARES, M. A escolarização da literatura infantil e juvenil. In: EVANGELISTA, A. A. M. (org.). A escolarização da leitura literária: o jogo do livro infantil e juvenil. Belo Horizonte: Autêntica, 2001. p. $17-48$.

TAMARITI, J. Educar o soberano: crítica ao iluminismo pedagógico de ontem e de hoje. São Paulo: Cortez, 1999.

TAUVERON, C. A escrita literária na escola: condições e obstáculos. Educar em Revista, Curitiba, n. 52, p. 85-101, abr./jul. 2014.

TOASSI, L. L.; LACOWICZ, S. D. A estética da recepção e o ensino de literatura na escola. Cad. PDE, Curitiba, v. 1, p. 1-19, 2013. Versão online. Disponível em: https://bit.ly/3v9cglB. Acesso em: 9 mar. 2021.

VIGOTSKY, L. S. A formação social da mente. São Paulo: Martins Fontes, 2000a.

VIGOTSKY, L. S. Pensamento e Linguagem. São Paulo: Martins Fontes, $2000 \mathrm{~b}$.

VIGOTSKY, L. S. Teoria e Método em Psicologia. São Paulo: Martins Fontes, 2004.

\section{Correspondência}

Raimundo Nonato de Oliveira Falabelo: Doutor em Educação (UNIMEP/Piracicaba/SP), Especialista em Literatura, Leitura e Formação de Leitores (UFPA), Prof. da Faculdade de Educação e Ciências Sociais - Curso de Pedagogia - Campus Abaetetuba/UFPA. Prof. do Programa de Mestrado em Educação e Cultura - PPGEDUC - Campus Universitário de Cametá/UFPA. Coordenador do Projeto de Pesquisa: A mediação das dimensões afetiva/ emocional e conhecimento nos processos interativos de leitura e escrita". Coordenador do GEPLAES - Grupo de Estudos e Pesquisa em Linguagem, Alfabetização, Emoções e Subjetividade.

E-mail: falabelo@ufpa.br

Orcid: https://orcid.org/0000-0003-1193-8072

Texto publicado em Currículo sem Fronteiras com autorização dos autores. 